\title{
Good practices for physical restraint in intensive care units: integrative review
}

\author{
Boas práticas para restrição física em unidades de terapia intensiva: revisão integrativa \\ Buenas prácticas para restricción física en unidades de cuidados intensivos: revisión integrativa
}

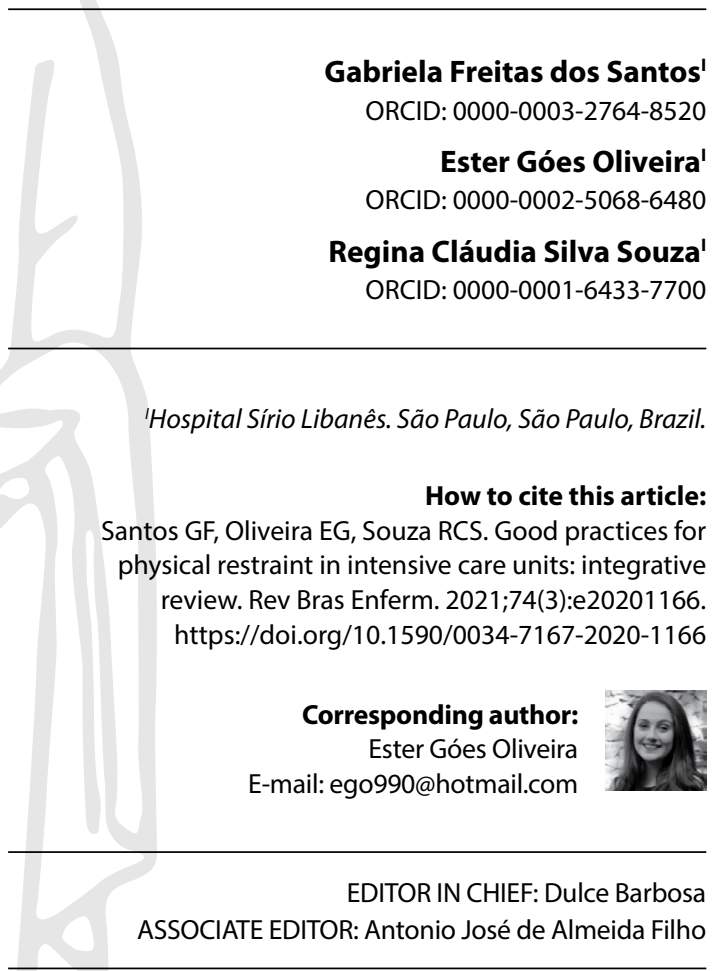

Submission: $11-25-2020$

Approval: 02-22-2021

\begin{abstract}
Objectives: to describe the available evidence on indications, complications, care and alternative strategies in the use of physical restraint in adult patients in Intensive Care Units. Methods: an integrative review conducted in the LILACS, Nursing Database, Indice Bibliográfico Español en Ciencias de la Salud, Scopus and CINAHL databases and the PubMed portal, in the period from June to August 2018. Results: the final selection was of 19 articles, from which the indications, complications, care and alternative strategies were extracted. The studies were conducted between the years 2003 and 2018, with a predominance of the United States; they were mostly classified (58\%) in level 6 evidence, being performed by nurses, with multi-professional participation of psychologists, pharmacists, physicians, and nurses. Conclusions: the most common practices regarding physical restriction were described, and the need for the elaboration and implementation of protocols on intervention to support decision making was observed.

Descriptors: Physical Restrictions; Intensive Care Unit; Patient Safety; Evidence-Based Practice; Nursing Care.
\end{abstract}

\section{RESUMO}

Objetivos: descrever as evidências disponíveis sobre indicações, complicações, cuidados e estratégias alternativas no uso da restrição física em pacientes adultos de Unidades de Terapia Intensiva. Métodos: revisão integrativa realizada nas bases LILACS, Base de Dados em Enfermagem, Índice Bibliográfico Español en Ciencias de la Salud, Scopus e CINAHL e no portal PubMed, no período de junho a agosto de 2018. Resultados: a seleção final foi de 19 artigos, dos quais foram extraídas as indicações, complicações, cuidados e estratégias alternativas. Os estudos foram realizados entre os anos de 2003 e 2018, com predomínio dos Estados Unidos; foram classificados em sua maioria (58\%) em evidência nível 6, sendo realizados por enfermeiros, com participação multiprofissional de psicólogos, farmacêuticos, médicos e enfermeiros. Conclusões: descreveram-se as práticas mais comuns quanto à restrição física, e observou-se a necessidade da elaboração e implementação de protocolos sobre a intervenção para embasar a tomada de decisão.

Descritores: Restrição Física; Unidade de Terapia Intensiva; Segurança do Paciente; Prática Clínica Baseada em Evidências; Cuidados de Enfermagem.

\section{RESUMEN}

Objetivos: describir las evidencias disponibles sobre indicaciones, complicaciones, cuidados y estrategias alternativas en el uso de la restricción física en pacientes adultos de Unidades de Cuidados Intensivos. Métodos: revisión integrativa realizada en las bases LILACS, Base de Datos en Enfermería, Índice Bibliográfico Español en Ciencias de la Salud, Scopus y CINAHL y en portal PubMed, de junio a agosto de 2018. Resultados: la selección final fue de 19 artículos, de los cuales fueron extraídas las indicaciones, complicaciones, cuidados y estrategias alternativas. Los estudios fueron realizados entre los años de 2003 y 2018, con predominio de Estados Unidos; fueron clasificados en su mayoría (58\%) en evidencia nivel 6 , siendo realizados por enfermeros, con participación multiprofesional de psicólogos, farmacéuticos, médicos y enfermeros. Conclusiones: describieron las prácticas más comunes cuanto a la restricción física, y se observó la necesidad de elaboración e implementación de protocolos sobre la intervención para embazar la toma de decisión.

Descriptores: Restricción Física; Unidades de Cuidados Intensivos; Seguridad del Paciente; Práctica Clínica Basada en Evidencias; Cuidados de Enfermería. 


\section{INTRODUCTION}

The Intensive Care Unit (ICU) is a highly complex environment with advanced technological and computerized apparatus, where complex and invasive procedures are performed ${ }^{(1)}$. Patients admitted to these units, due to certain conditions, may intentionally or unintentionally remove devices and present a high risk of falling, which often leads to the need to use some form of protection to ensure their safety ${ }^{(2)}$.

Physical restraint, also identified as mechanical restraint or physical restraint, is one of the most common strategies in situations in which the safety of the critically ill patient is at risk. According to the Centers for Medicare \& Medicaid Services, this practice is defined as any manual method, physical or mechanical device, material or equipment attached to or adjacent to the patient's body that restricts access to the body, immobilizes or reduces the patient's ability to move arms, legs, body or head freely ${ }^{(3)}$.

Studies have analyzed the different reasons for the use of physical restraint in the intensive care setting, as well as described its incidence, which ranges from $0 \%$ in some European countries to over $75 \%$ in North America ${ }^{(2)}$. In Brazil, few statistical data on prevalence rates in institutions were found in the literature. However, the insertion of some institutions in the country in the Magnet Journey and the promotion of patient safety culture have caused this indicator to receive more attention, which has led to discussions and reflections on best practices in relation to the strategy. There is data ${ }^{(4)}$ which confirms a higher prevalence of the use of physical restraint within the ICU environment (93.3\%), when compared to the medical clinic (50.9\%) and the surgical clinic (3.8\%).

There are many repercussions of physical restriction among patients, involving increased risk of delirium and ICU length of stay ${ }^{(2,4)}$. However, most institutions do not have evidence-based guidelines, the knowledge of professionals about the problem is incipient, and the literature has a significant gap on the subject. This reflects inappropriate use of physical restraint in institutions, which negatively impacts health outcomes. Thus, it is relevant to identify indications, complications, care and alternative strategies in the literature that can improve its use in Intensive Care Units.

\section{OBJECTIVES}

To describe the available evidence on indications, complications, care and alternative strategies in the use of physical restraint in adult patients in Intensive Care Units.

\section{METHODS}

Integrative literature review that met the recommended steps for the method ${ }^{(5)}$. For the search of the studies, which occurred in October 2018, two independent reviewers used the following guiding question based on the acronym PICO: "What evidence is available in the literature on the indications, care, complications, and alternative strategies in the use of physical restraint in adult patients admitted to Intensive Care Units?" A third reviewer contributed when there were disagreements at this stage of article selection.
The search was conducted in the databases Latin American Caribbean Literature in Health Sciences (LILACS), Database in Nursing (BDENF), Index Bibliográfico Español en Ciencias de la Salud (IBECS), Elsevier SciVerse Scopus (Scopus) and Cumulative Index Health Literature (CINAHL), and the National Library of Medicine (PubMed) portal from September to November 2018. The information extracted from the publications was manually entered into a spreadsheet prepared by the researchers for this purpose.

The search taxonomies included the descriptors "Physical Restraint", "Intensive Care Unit", "Critical Care Nursing", "Nursing Care", according to the Descriptors in Health Sciences (DECS) and Medical Subject Headings (MeSH); and were combined with the Boolean operators AND (restrictive combination), OR (additive combination) and NOT (excluding combination) in the different databases (Chart 1). The inclusion of the descriptors "Advanced Practice Nursing", "Nursing Team", "Nursing Assessment" and "Patient Care Plan" was done to broaden the search, since only the descriptors referring to the question brought few results.

Chart 1 - Search strategies used for article selection, São Paulo, São Paulo, Brazil, 2018

\begin{tabular}{|c|c|c|}
\hline & Search strategy & Observations \\
\hline PubMed & $\begin{array}{l}\text { (("Restraint, Physical"[Mesh]) } \\
\text { AND "Intensive Care } \\
\text { Units"[Mesh]) AND } \\
\text { ("Nursing"[Mesh] OR “Critical } \\
\text { Care Nursing"[Mesh] } \\
\text { OR "Advanced Practice } \\
\text { Nursing"[Mesh] OR "Nursing, } \\
\text { Team"[Mesh] OR “Nursing } \\
\text { Care"[Mesh] OR "Nursing } \\
\text { Assessment"[Mesh] } \\
\text { OR "Patient Care } \\
\text { Planning"[Mesh] OR } \\
\text { "Nurses"[Mesh]) }\end{array}$ & \\
\hline CINAHL & $\begin{array}{l}\text { SU intensive care AND SU } \\
\text { restraint AND physical }\end{array}$ & $\begin{array}{l}\text { Limiters - Exclude records } \\
\text { from MEDLINE; Special } \\
\text { Interest: Advanced } \\
\text { Nursing Practice, } \\
\text { Evidence-Based Practice, } \\
\text { Nursing Administration, } \\
\text { Nursing Language/ } \\
\text { Classification, Patient } \\
\text { Safety } \\
\text { Expanders - Apply } \\
\text { equivalent subjects } \\
\text { Search Modes - Boolean/ } \\
\text { Phrase }\end{array}$ \\
\hline Scopus & $\begin{array}{l}\text { (TITLE (physical AND } \\
\text { restraint) AND KEY } \\
\text { (evidence OR standard* OR } \\
\text { protocol* OR guidelines) } \\
\text { OR KEY ("Patient Safety") } \\
\text { OR KEY ("Nursing" OR } \\
\text { "Critical Care Nursing" OR } \\
\text { "Advanced Practice Nursing" } \\
\text { OR "Nursing, Team" OR } \\
\text { "Nursing Care" OR"Nursing } \\
\text { Assessment" OR "Patient } \\
\text { Care Planning" OR "Nurses") } \\
\text { AND KEY (intensive AND } \\
\text { care AND unit*) AND NOT } \\
\text { TITLE-ABS-KEY (psychiatr*)) }\end{array}$ & \\
\hline
\end{tabular}

To be continued 
Chart 1 (concluded)

\begin{tabular}{|l|l|l|}
\hline & Search strategy & Observations \\
\hline & (tW:("containment”)) & \\
& AND (tw:( unit\$)) AND & \\
& $($ tw:(intensive care)) & Filters: \\
Virtual & $($ tw:("immobilization”)) & BDENF \\
Health & AND (tw:(unit\$)) AND & LILACS \\
Library & (tw:(intensive care)) & IBECS \\
(VHL) & (tw:("physicalrestriction”)) & \\
& AND (tw:(unit\$)) AND & \\
& (tw:(intensive care)) AND & \\
& (tw:(intensive care)) & \\
\hline
\end{tabular}

Inclusion criteria for the selected articles were primary studies that addressed the practice of physical restraint in the ICU and were indexed in the selected databases, without delimitation of study time and in English, Spanish and Portuguese. Were excluded secondary studies, conducted with psychiatric patients, children and animals; with qualitative design; editorials, annals; and that were not performed in ICU.

The reference used for the classification of the level of evidence was Melnyk's ${ }^{(6)}$, and the variables extracted from the studies were Country, Training of professionals, Year of publication, Design, Care, Complications, Indications, and Alternative strategies related to the practice of physical restriction. Mendley software was used to manage the references.

\section{RESULTS}

A total of 149 articles were identified in the databases, 63 in the VHL, 42 in Scopus, 30 in PubMed, and 14 in CINAHL. Of these, 31 articles were duplicates. After the first reading (titles and abstracts), 79 articles were excluded. Then, a careful reading was made of the remaining 39 articles, and 20 were excluded according to the study criteria (Figure 1). Thus, 19 articles were selected for the final review (Chart 2).

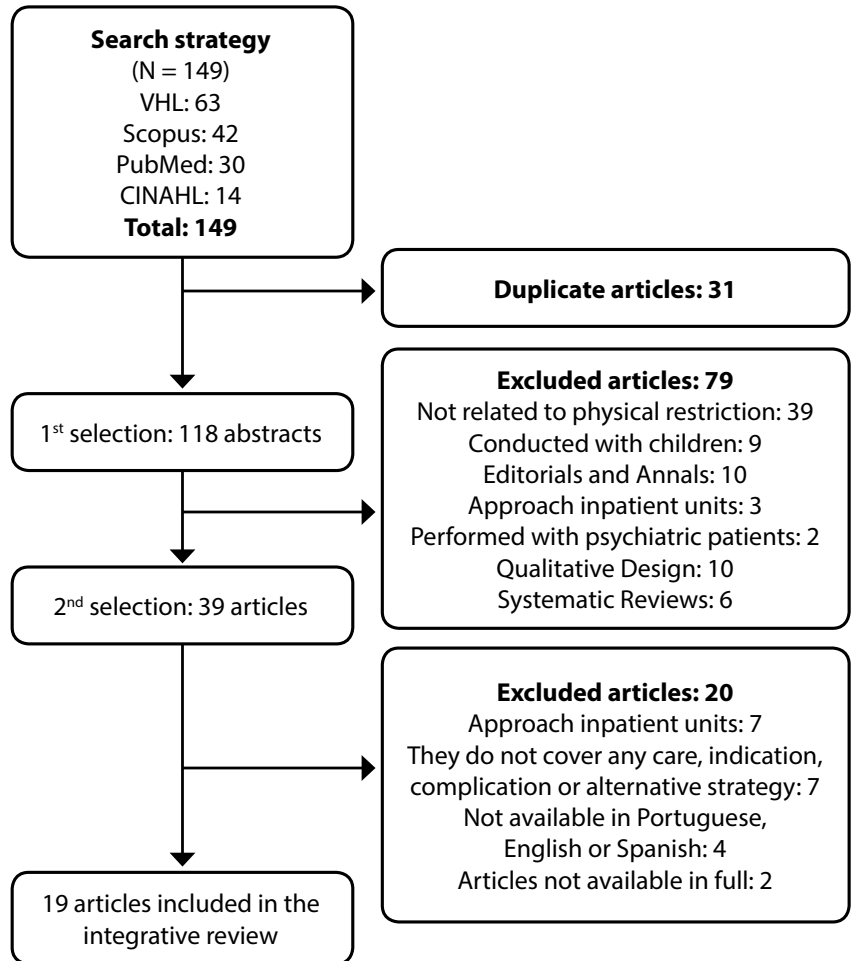

Figure 1 - Flowchart of selected articles in the integrative review, São Paulo, São Paulo, Brazil, 2019

The publication period of the studies occurred between the years 2003 and 2018, in various countries, with a predominance of the United States (32\%), followed by the European continent (26\%). The remaining papers are distributed among Canada, Jordan, Taiwan, China, Egypt, and South Korea. Eleven studies (58\%) have level 6 evidence; two (11\%), level 4; and six (31\%), level 3, being mostly conducted ( $84 \%)$ by nurses, with multidisciplinary participation of psychologists, pharmacists, physicians and nurses (Chart 2).

Chart 2 - Summary of the articles selected regarding identification, professional background, country, study design, and level of evidence, São Paulo, São Paulo, Brazil, 2019

\begin{tabular}{|l|l|l|l|l|c|}
\hline AUTHOR & YEAR & PROFESSIONAL TRAINING & COUNTRY & DESIGN & LEVEL OF EVIDENCE \\
\hline Van de Kooi AW et al. ${ }^{(7)}$ & 2015 & Doctor & The Netherlands & Cross-sectional study & 6 \\
\hline Benbenbishty J et al. ${ }^{(8)}$ & 2010 & Nurse and doctor & 9 countries in Europe & Cross-sectional study & 6 \\
\hline Lin Y-L et al. ${ }^{(9)}$ & 2018 & Nurse and doctor & Taiwan & Before-and-after study & 3 \\
\hline Hall DK et al. ${ }^{(10)}$ & 2018 & Nurse & USA & Before-and-after study & 3 \\
\hline Lynn LL et al. ${ }^{(11)}$ & 2017 & Nurse & USA & Before-and-after study & 3 \\
\hline Luk E et al. ${ }^{(12)}$ & 2015 & Nurse, pharmacist and physician & Canada & Cross-sectional study & 6 \\
\hline Kandeel NA et al. ${ }^{(13)}$ & 2013 & Nurse & Egypt & Observational study & 4 \\
\hline Choi E et al. ${ }^{(14)}$ & 2003 & Nurse & South Korea & Cross-sectional study & 6 \\
\hline Johnson K et al. ${ }^{(15)}$ & 2016 & Nurse & USA & Before-and-after study & 3 \\
\hline Turgay AS et al. ${ }^{(16)}$ & 2009 & Nurse & Turkey & Cross-sectional study & 6 \\
\hline Perren A et al. ${ }^{(17)}$ & 2015 & Doctor and psychologist & Switzerland & Prospective observational study & \\
\hline
\end{tabular}


Chart 2 (concluded)

\begin{tabular}{|l|l|l|l|l|c|}
\hline AUTHOR & YEAR & PROFESSIONAL TRAINING & COUNTRY & DESIGN & LEVEL OF EVIDENCE \\
\hline De Jonghe B et al. ${ }^{(18)}$ & 2013 & Doctor & France & Cross-sectional study & 6 \\
\hline Vance DL ${ }^{(19)}$ & 2003 & Nurse & USA & Before-and-after study & 3 \\
\hline Yönt GH et al. ${ }^{(20)}$ & 2014 & Nurse & Turkey & Cross-sectional study & 6 \\
\hline GuT et al. ${ }^{(21)}$ & 2019 & Nurse & China & Cross-sectional study & 6 \\
\hline Martin B et al.(22) & 2005 & Nurse & USA and Norway & Cross-sectional study & 6 \\
\hline Guenette M et al.(23) & 2017 & Pharmacist, nurse and doctor & Canada & Cross-sectional study & 6 \\
\hline Suliman M(24) & 2018 & Nurse & Jordan & Cross-sectional study & 6 \\
\hline Hevener S et al. ${ }^{(25)}$ & 2016 & Nurse & USA & Quasi-experimental study & 3 \\
\hline
\end{tabular}

The studies' variables were categorized into Indications, complications, and alternative strategies (Chart 3); and Care for the use of physical restraint (Chart 4).

The reasons described in the studies that led professionals to use physical restraint were concern to ensure continuity of treatment, self-extubating, altered level of consciousness such as agitation, disorientation, confusion and delirium, aggressiveness, sleepiness and coma ${ }^{(7-8)}$, prevention of loss or dislodgement of invasive therapeutic devices being the main indication ${ }^{(9-10)}$.

Also cited as "indication" were aspects related to the safety of the patient, the staff and other patients, the difficulty of direct observation of the patient by the nursing staff, the high risk of falls and their prevention ${ }^{(8-9,11-15)}$, staff convenience ${ }^{(14,16)}$, sedation ${ }^{(17)}$, weaning from sedatives ${ }^{(17-18)}$, the post-anesthesia recovery process $^{(9)}$, suggestions made by staff members, patients themselves, their families, or physicians ${ }^{(12,14,19)}$; lack of understanding and/ or resistance to the need for the use of therapeutic devices ${ }^{(13)}$; impossibility and/or inability of verbal communication from the patient ${ }^{(7,9) ;}$; preservation of the patient's posture in bed ${ }^{(13,20)}$; presence of an unstable fracture ${ }^{(7)}$; prevention of wound contamination ${ }^{(11)}$; patient in isolation ${ }^{(12)}$ and age above 75 years $^{(21)}$.

Complications resulting from physical restriction include alterations in the level of consciousness, cognitive and physical $^{(14)}$, patient discomfort ${ }^{(18)}$, increased risk of device removal ${ }^{(22)}$, risk of psychomotor agitation ${ }^{(13,22-23)}$, perceived loss of dignity, post-traumatic stress disorder ${ }^{(18)}$, anxiety and crying ${ }^{(13)}$.

Physical changes in the restricted limbs such as skin lesions s $^{(1,24)}$, edema $^{(13,24-25)}$, pressure ulcers ${ }^{(13)}$, bruising and hyperemia ${ }^{(13,24)}$, skin necrosis ${ }^{(13)}$ and death ${ }^{(24)}$ are highlighted in the studies (Chart 3 ).

The alternative strategies identified refer to the team's work process, the patients, the family, the promotion of comfort, and the use of medications. In the first condition is the adequate nurse/ patient relationship ${ }^{(21)}$, the reduction of work overload, the sharing of responsibilities with the multi-professional team ${ }^{(21)}$ and discussion of alternatives to physical restraint during nursing visits ${ }^{(11)}$.

Provide distractions such as television, games, magazines, and pencils ${ }^{(15)}$ as well as promoting sleep hygiene ${ }^{(15)}$ are the patientrelated interventions. For the family, interventions regarding the visitation period can be observed ${ }^{(13,15)}$. Among those classified as comfort promoting ${ }^{(13,24)}$, are the use of analgesics ${ }^{(21)}$, the positioning of the patient and the use of special mattresses.
Chart 3 - Indications, complications and alternative strategies related to the practice of physical restraint of patients admitted to Intensive Care Units, São Paulo, São Paulo, Brazil, 2019

\section{Indications}

Prevent devices from being lost or misplaced ${ }^{(7-9,12-14,16-17,19-22,25)}$ (adverse events), ensure continuity of treatment ${ }^{(11,19,23,25)}$, altered level of consciousness (agitation, restlessness, disorientation, confusion, aggressiveness, comatose, drowsiness ${ }^{(7-9,12,14,16-18,22-23)}$, keep the team safe ${ }^{(7)}$, maintain the safety of other patients, maintain patient safety ${ }^{(7-8,10-13,20)}$, delirium ${ }^{(7-8,12,17,21)}$, patients with impaired verbal communication ${ }^{(9)}$, age above 75 years ${ }^{(21)}$, prevent wound contamination ${ }^{(11)}$, insufficient nursing staff ${ }^{(8,13)}$, misunderstanding/ resistance about the need for care or therapeutic devices ${ }^{(13)}$, request from more than one staff member, patient, family, or other physicians $\mathrm{s}^{(14,16)}$, patient in an isolated room ${ }^{(12)}$, post-anesthesia recovery ${ }^{(9)}$, sedation weaning and insufficient sedation ${ }^{(17-18)}$, presence of an unstable fracture ${ }^{(7)}$ and proper patient positioning ${ }^{(13,20)}$

\section{Complications}

Skin injuries ${ }^{(13,16)}$, hyperemia ${ }^{(13,24)}$, edema of the restricted limb ${ }^{(13,24-}$ ${ }^{25)}$, psychomotor agitation ${ }^{(13,22-23)}$, pressure ulcer ${ }^{(13)}$, bruises on the restricted limb $b^{(13)}$, death ${ }^{(24)}$, skin necrosis in the restricted $\operatorname{limb}^{(13)}$, anxiety ${ }^{(13)}$, crying ${ }^{(13)}$, patient discomfort, perceived loss of dignity ${ }^{(18)}$, post-traumatic stress disorder ${ }^{(18)}$ and device removal ${ }^{(22)}$.

\section{Alternative Strategies}

Administration of painkillers and sedation medication ${ }^{(12-13,21)}$ extension of the permanence period of family members and caregivers with the patient ${ }^{(11,13,15)}$, appropriate nurse-patient relationship ${ }^{(21)}$, co-participation and co-responsibility of the multidisciplinary team in patient care ${ }^{(11)}$, sleep hygiene promotion ${ }^{(15)}$, therapeutic distraction strategies such as television, games, exercises, music, magazines, and pencils to keep the hands busy ${ }^{(11)}$.

An extensive repertoire of care concerning the practice of physical restraint was identified, listed in Chart 4. They are related to patient assessment, communication, and safety. Among the assessment cares, the following stand out: assessment of the peripheral perfusion of the restricted limb ${ }^{(10,13)}$, of skin integrity ${ }^{(9,13,24)}$, the level of sedation, psychomotor agitation, level of consciousness ${ }^{(12-13)}$ and mobility of the restricted limb $b^{(10,13)}$.

Patient safety care includes the use of sedation under certain conditions ${ }^{(12)}$, pharmacological optimization before and after the use of physical restraint ${ }^{(23)}$, measures to promote tranquility ${ }^{(9,12,17)}$, pain treatment ${ }^{(12)}$, material used for making the physical restriction $^{(13)}$, comfort measures ${ }^{(13,24)}$ and use of materials that allow limb movement and avoid impairment of fine motor functions ${ }^{(7)}$. 
Regarding communication, special attention is given to the documentation of the procedure ${ }^{(7,10,13,18,22,24)}$, communication between professionals and family ${ }^{(9,13)}$, authorization and consent ${ }^{(7,9)}$, visit routines ${ }^{(13)}$, involvement of the medical team in joint decision making with the team ${ }^{(24)}$ and review of the prescription daily ${ }^{(9)}$.

Chart 4 - Care related to the practice of physical restraint of patients admitted to Intensive Care Units, São Paulo, São Paulo, Brazil, 2018

\begin{tabular}{|c|c|}
\hline Category & Care \\
\hline $\begin{array}{l}\text { Patient } \\
\text { Assessment }\end{array}$ & $\begin{array}{l}\text { Frequent evaluation of the restrained limb } \\
\text { related to skin integrity, peripheral perfusion } \\
\text { and presence of tourniquet, assessment of } \\
\text { pain, delirium, sedation, agitation, cognitive } \\
\text { and behavioral status of the patient, frequent } \\
\text { evaluation of alternative strategies for } \\
\text { the replacement of the physical restraint, } \\
\text { reassessment of the indication for physical } \\
\text { restraint every eight hours, assessment of } \\
\text { mobility and sensibility of the restrained limb, } \\
\text { and assessment of the patient's appropriate level } \\
\text { of sedation. }\end{array}$ \\
\hline Communication & $\begin{array}{l}\text { Reorientation of the patient, often about } \\
\text { the use of physical restraint, prescription of } \\
\text { physical restraint for no more than } 24 \text { hours, } \\
\text { orientation to the patient about the purpose and } \\
\text { importance of the devices in the quality of care, } \\
\text { detailed documentation of the physical restraint } \\
\text { procedure, participation of the medical team } \\
\text { in the indication of physical restraint, effective } \\
\text { communication between patient, professional } \\
\text { and family, and obtaining consent on the use } \\
\text { of physical restraint with the patient, legal } \\
\text { representative and family. }\end{array}$ \\
\hline Patient Safety & $\begin{array}{l}\text { Promotion of patient comfort with sedation, } \\
\text { narcotic analgesia, positioning of the patient and } \\
\text { use of mattresses or special beds, release of the } \\
\text { restricted limb every two hours for } 15 \text { minutes, } \\
\text { use of restraint made with fabrics less harmful } \\
\text { to the skin, maintenance of patient safety, } \\
\text { proper positioning of devices, use of strategies } \\
\text { that promote patient calm and tranquility, } \\
\text { pain management, administration of sedation } \\
\text { medications when needed, use of restraints } \\
\text { that allow limb movement but avoid fine motor } \\
\text { functions, standardization of care and indications } \\
\text { related to the use of physical restraint, use of } \\
\text { pharmacological options before and after the use } \\
\text { of physical restraint. }\end{array}$ \\
\hline
\end{tabular}

\section{DISCUSSION}

Nowadays, the concern with patient safety and its relation to the quality of care offered by health services is well known. An attempt is made to implement the necessary treatment, but without significant harm. The use of physical restraint in ICU patients covers this issue, since, despite its risks and biopsychosocial impact, its use is essential at certain times of treatment.

Our review searched the literature for indications, complications, care, and alternative strategies related to the use of physical restraint in adult ICU patients. Other reviews also proposed to study the theme, such as those conducted by Perez et al. ${ }^{(26)}$ and by $\mathrm{Li}^{(27)}$, who addressed the nurse's experience in making a decision about the use of physical restraint and patient and family experience.
Among the 19 articles selected for the present study, most were conducted in North America and Europe. In other investigations ${ }^{(26-28)}$, there was also a predominance of these continents, which leads us to reflect on the more consistent safety culture in these places. Most studies were characterized as level 6 evidence, which are descriptive studies, indicating the need for research with experimental designs of better scientific rigor, in which interventions related to physical restriction can be better evaluated. Seven articles were conducted in the last five years and in several countries, demonstrating the timeliness, plurality, and representativeness of the information found, which contributes to a better understanding of the problem.

Regarding the indications for the use of physical restraint, they are associated with the prevention of adverse events ${ }^{(21,26,29)}$. The rate of health care-related adverse events was observed over eight years in an $\mathrm{ICU}^{(30)}$, and it was found that the devices most frequently removed by the patients were, respectively, the gastric tube, intracranial devices, and endotracheal tubes, and that in $81.6 \%$ of these removals, the patient removed the devices by himself.

Accidental removal of devices is also related to the patient's score on the Richmond Agitation-Sedation Scale (RASS) ${ }^{(30)}$, with the highest number of events occurring with RASS between +1 and +3 . Therefore, the assessments of level of consciousness and level of sedation emphasize the contribution of these parameters in decision making about restraint. This aspect has not been validated in a systematic review ${ }^{(31)}$, whose results were inconsistent as to the benefit of using physical restraint for the prevention of unplanned extubating. Thus, this decision needs to be considered from individual and institutional perspectives.

Pain management ${ }^{(21)}$ and the management of a protocol of sedation and analgesia by nurses provide autonomy and can collaborate not only for decision making in the use of physical restraint, but also to reduce the prevalence of this indicator. In this sense, improving the level of knowledge of nurses on the subject provides a better understanding of the complexity of the intervention ${ }^{(29)}$. The very implementation of guidelines and protocols for the use of physical restraint favors a reflection of professionals on the problem and awakens greater responsibility in decision making ${ }^{(29)}$. In a study that compared ICUs in Norway and the United States, the use of physical restraint in Norway showed a prevalence rate of $0 \%$. It was observed that in the American ICUs, the use of sedative and/or analgesic drugs was lower; and in the Norwegian ICUs, the nurse/patient relationship was more adequate ${ }^{(22)}$.

Studies have analyzed the different reasons for the use of physical restraint in the intensive care setting, and this information is confirmed by the results described in our review. They show as the first indication the risk for interruption of therapeutic processes ${ }^{(32)}$ - for example, the externalization of medical devices (tubes and catheters $)^{(7,32)}$. Next are the risk of falling, aggressiveness to self or others, presence of delirium, altered level of consciousness, among others ${ }^{(7,20,32-34)}$. Large units and fewer nurses available in the daytime were also factors that contributed to the use of physical restraint ${ }^{(8)}$. These are important elements for the understanding of the problematic issue and strategies that can be implemented in an attempt to decrease the prevalence of this indicator. 
Care can be classified into three major domains - assessment, communication, and patient safety - that guide the main interventions related to the practice of physical restriction and health care. They are essential to maintain the quality of care and better health outcomes.

Surveillance, monitoring, and frequent evaluation of the body region that has been restrained, vital parameters, patient symptoms, and clinical condition are the most relevant care found in the studies. Considering the impact of complications in the use of physical restraint, undesirable events such as skin lesions ${ }^{(5,26,30)}$, hyperemia ${ }^{(30,35)}$, edema of the restricted limb ${ }^{(29-30,35)}$, psychomotor agitation $^{(2,9,16-17,29,35-36)}$, pain, delirium, sedation and agitation ${ }^{(10,29)}$ need to be avoided. Therefore, it is essential to develop protocols or guidelines and continuing education on the subject for health professionals, since nurses have little knowledge on the subject ${ }^{(29)}$.

The practice of detailed documentation about the use of physical restraint is important, but it is not always complete. A study that characterized the use of physical restraint identified that $51.3 \%$ of cases recorded by the nursing staff did not include information about the time of withdrawal, patient response after restraint, associated complications, and informed consent ${ }^{(21)}$. Professionals often record only the time of application, location and types of restrictions, which demonstrates a gap in knowledge by nurses about the importance of proper documentation of the practice. Associated with this fact, not all units have instituted an annotation standard(29).

Although the importance of obtaining consent on the use of physical restraint is emphasized ${ }^{(7,9)}$ with patient, family or legal representative, the literature ${ }^{(21)}$ brings that in less than a third of the patients, informed consent for the use of physical restraint was applied. Considering this practice in care is fundamental because it involves aspects related to dignity, safety, and respect for the patient and family. Communication is considered an aspect that distinguishes care ${ }^{(37)}$, as pointed out in the studies ${ }^{(2,5,10,35)}$ raised in this review, placing effective communication as essential care for the physically impaired patient.

Physical restraint can bring about a number of complications, as well as increase the likelihood of device removal. A study conducted in the ICU of a hospital in Italy found that patients using physical restraint removed more devices compared to those not restrained ${ }^{(30)}$. Perhaps this is due to inadequate management of other symptoms such as delirium, sedation, and pain.

As for clinical changes, these are conditions that, if the patient is properly evaluated and followed up by continuous surveillance, can be avoided or, if they occur, are of lesser intensity. No physical harm caused by physical restraint devices has been reported in three ICUs in Switzerland, where measures are in place that include a protocol for the use of physical restraint covering documentation in the patient's record of the reason, type, duration, and possible precautions required; the evaluation of all potential alternatives and eventually considered ineffective in restraining the patient; the special attention to the patient's dignity and comfort; the consensual approval between the nurse and the attending physician; the frequent evaluation of the suspension of physical restraint; and the use of a nurse-managed sedation and analgesia guideline ${ }^{(17)}$. This element reinforces the importance of incorporating the care described in this review into the practice of ICU professionals.
Complications such as bruising, redness, ulcers, and skin necrosis were correlated with patients' age and length of ICU stay. However, a negative correlation was evident between the occurrence of complications and the number of nurses per patient ${ }^{(13)}$. This information may demonstrate an association between complications and the structure and culture of healthcare organizations.

Alternative strategies to physical restraint have great importance in reducing the use and prevalence of this practice in intensive care units. The use of analgesics was identified as a protective factor for the use of physical restraint ${ }^{(21)}$, and it was observed that the administration of these drugs is an alternative to the practice ${ }^{(17)}$.

In this review, the articles ${ }^{(38)}$ cite interesting non-pharmacological alternatives to physical restraint, such as camouflaging or hiding accesses and tubes, distracting patients by occupying their hands, use of bed alarms for those patients with altered consciousness and risk of falling, and talking to patients ${ }^{(35)}$.

Strategies such as music, television, close observation, providing coloring and reading books, puzzles, talking to the patient, and encouraging family presence are considered potent in managing delirium and, if unsuccessful, are predictors of mechanical and chemical restraints ${ }^{(39)}$. Family participation in care ${ }^{(13,15)}$, comfort measures, sleep cycle promotion, and bedside caregivers bring a humanized care perspective that improves patient and family experience, which also contributes to less use of physical restraint.

Despite the diversity of alternative strategies that can be implemented, most nurses do not consider alternative methods to physical restraint and do not believe in the effectiveness of these methods ${ }^{(39)}$. In a study ${ }^{(38)}$ which proposed a rate-based initiative to reduce the use of physical restraint in Magnet Hospitals, administrative support, staff development, education, and multidisciplinary visits were important factors for a change in the behavior of professionals regarding the intervention. Perhaps this possibility of action results in assertive decision making by the teams and better understanding of the problem.

\section{Limitations of the study}

The limitations found were related to the level of evidence of the selected studies. There is no high level evidence available on the subject, impacting the practice and knowledge of teams working in ICU.

\section{Contributions to the Area}

This review provides the background for health care professionals on best practice in the use of physical restraint in Intensive Care Units.

\section{CONCLUSIONS}

The indications, care, complications and alternative strategies regarding physical restraint in adult patients in the ICU could be identified despite the fragility of the studies. These highlight the inappropriate use of physical restraint and the health professionals' lack of knowledge about the problem, showing that the construction and implementation of protocols and the education of professionals improve the team's decision making regarding the use of physical restraint. Thus, it is important to conduct studies 
of better methodological quality to confirm that the introduction of protocols decreases the prevalence rate of physical restraint as well as the incidence of delirium and other complications.

\section{FUNDING}

Instituto de Ensino e Pesquisa do Hospital Sírio-Libanês.

\section{REFERENCES}

1. Backes MTS, Erdmann AL, Büscher A. The living, dynamic and complex environment care in intensive care unit. Rev Latino-Am Enfermagem. 2015;23(3):411-8. https://doi.org/10.1590/0104-1169.0568.2570

2. Devlin JW, Skrobik Y, Gélinas C, Needham DM, Slooter AJC, Pandharipande PP, et al. Clinical practice guidelines for the prevention and management of pain, agitation/sedation, delirium, immobility, and sleep disruption in adult patients in the ICU. Crit Care Med [Internet]. 2018[cited 2019 Oct 8];46(9):e825-73. Available from: http://www.ncbi.nlm.nih.gov/pubmed/30113379

3. Medicare and Medicaid programs; hospital conditions of participation: patients' rights. Final Rule[Internet]. 1999 [cited 2020 Sep 30];(42 CFR 482). Available from: https://www.ncbi.nlm.nih.gov/pubmed/17171854

4. Souza LMS. Mechanical restraint in the hospital environment: a cross-sectional study [Dissertação] [Internet]. Niterói: Escola de Enfermagem da Universidade Federal Fluminense; 2018 [cited 2020 Sep 30]. Available from: https://app.uff.br/riuff/handle/1/7240

5. Mendes KDS, Silveira RCCP, Galvão CM. Integrative literature review: a research method to incorporate evidence in health care and nursing. Texto Contexto Enferm. 2008;17(4):758-64. https://doi.org/10.1590/S0104-07072008000400018

6. Fineout-Overholt E, Stillwell SB. Asking compelling, clinical questions. In: Fineout-Overholt E, Melnyk BM, (Ed). Evidence-based practice in nursing \& healthcare: a guide to best practice. 2nd ed. Philadelphia: Wolters Kluwer Health; 2011. p. 25-39.

7. Van der Kooi AW, Peelen LM, Raijmakers RJ, Vroegop RL, Bakker DF, Tekatli H, et al. Use of physical restraints in Dutch intensive care units: a prospective multicenter study. Am J Crit Care [Internet]. 2015[cited 2020 Sep 30];24(6):488-95. Available from: http://ajcc.aacnjournals.org/ cgi/doi/10.4037/ajcc2015348

8. Benbenbishty J, Adam S, Endacott R. Physical restraint use in intensive care units across Europe: the PRICE study. Intensive Crit Care Nurs [Internet]. 2010 [cited 2020 Sep 30];26(5):241-5. Available from: https://linkinghub.elsevier.com/retrieve/pii/S0964339710000686

9. Lin YL, Liao CC, Yu WP, Chu TL, Ho LH. A multidisciplinary program reduces over 24 hours of physical restraint in neurological intensive care unit. J Nurs Res. 2018;26(4):288-96. https://doi.org/10.1097/jnr.00000000000000251

10. Hall DK, Zimbro KS, Maduro RS, Petrovitch D, Ver Schneider P, Morgan M. Impact of a restraint management bundle on restraint use in an intensive care unit. J Nurs Care Qual [Internet]. 2018 [cited 2020 Sep 30];33(2):143-8. Available from: http://www.ncbi.nlm.nih.gov/pubmed/28658189

11. Lynn LL, Brookes JM. Changing perceptions of physical restraint use in the ICU. Nurs Crit Care. 2017;12(6):41-4. https://doi.org/10.1097/01. CCN.0000521939.91085.6f

12. Luk E, Burry L, Rezaie S, Mehta S, Rose L. Critical care nurses' decisions regarding physical restraints in two Canadian ICUs: a prospective observational study. Can J Crit care Nurs [Internet]. 2015 [cited 2020 Sep 30];26(4):16-22. Available from: http://www.ncbi.nlm.nih.gov/ pubmed/26837121

13. Kandeel NA, Attia AK. Physical restraints practice in adult intensive care units in Egypt. Nurs Health Sci [Internet]. 2013 [cited 2020 Sep 30];15(1):79-85. Available from: http://doi.wiley.com/10.1111/nhs.12000

14. Choi E, Song M. Physical restraint use in a Korean ICU. J Clin Nurs [Internet]. 2003[cited 2020 Sep 30];12(5):651-9. Available from: http://doi. wiley.com/10.1046/j.1365-2702.2003.00789.x

15. Johnson K, Curry V, Steubing A, Diana S, McCray A, McFarren A, et al. A non-pharmacologic approach to decrease restraint use. Intensive Crit Care Nurs [Internet]. 2016 [cited 2020 Sep 30];34:12-9. Available from: http://www.ncbi.nlm.nih.gov/pubmed/26652790

16. Turgay AS, Sari D, Genc RE. Physical restraint use in Turkish intensive care units. Clin Nurse Spec [Internet]. 2009 [cited 2020 Sep 30];23(2):6872. https://doi.org/10.1097/NUR.0b013e318199125c

17. Perren A, Corbella D, lapichino E, Di Bernardo V, Leonardi A, Di Nicolantonio R, et al. Physical restraint in the ICU: does it prevent device removal? Minerva Anestesiol [Internet]. 2015 [2020 Sep 30];81(10):1086-95. Available from: http://www.ncbi.nlm.nih.gov/pubmed/25338282

18. De Jonghe B, Constantin JM, Chanques G, Capdevila X, Lefrant JY, Outin H, et al. Physical restraint in mechanically ventilated ICU patients: a survey of French practice. Intensive Care Med [Internet]. 2013[cited 2020 Sep 30];39(1):31-7. Available from: http://link.springer. com/10.1007/s00134-012-2715-9

19. Vance DL. Effect of a treatment interference protocol on clinical decision making for restraint use in the intensive care unit: a pilot study. AACN Clin Issues [Internet]. 2003 Feb; 14(1):82-91. Available from: http://www.ncbi.nlm.nih.gov/pubmed/12574706

20. Yönt GH, Korhan EA, Dizer B, Gümüş F, Koyuncu R. Examination of ethical dilemmas experienced by adult intensive care unit nurses in physical restraint practices. Holist NursPract. 2014;28(2):85-90. https://doi.org/10.1097/HNP.0000000000000013

21. Gu T, Wang X, Deng N, Weng W. Investigating influencing factors of physical restraint use in China intensive care units: a prospective, crosssectional, observational study. Aust Crit Care [Internet]. 2019 [cited 2020 Sep 30];32(3):193-8. Available from: https://linkinghub.elsevier. com/retrieve/pii/S1036731417303971 
22. Martin B, Mathisen L. Use of physical restraints in adult critical care: a bicultural study. Am J Crit Care [Internet]. 2005 [cited 2020 Sep 30];14(2):133-42. Available from: http://www.ncbi.nlm.nih.gov/pubmed/15728955

23. Guenette M, Burry L, Cheung A, Farquharson T, Traille M, Mantas I, et al. Psychotropic drug use in physically restrained, critically ill adults receiving mechanical ventilation. Am J Crit Care. 2017;26(5):380-7. https://doi.org/10.4037/ajcc2017677

24. Suliman M. Prevalence of physical restraint among ventilated intensive care unit patients. J Clin Nurs. 2018;27(19-20):3490-6. https://doi. org/10.1111/jocn.14588

25. Hevener S, Rickabaugh B, Marsh T. Using a decision wheel to reduce use of restraints in a medical-surgical intensive care unit. Am J Crit Care [Internet]. 2016 [cited 2020 Sep 30];25(6):479-86. Available from: http://www.ncbi.nlm.nih.gov/pubmed/27802948

26. Perez D, Peters K, Wilkes L, Murphy G. Physical restraints in intensive care- an integrative review. Aust Crit Care [Internet]. 2019 [cited 2020 Sep 30];32(2):165-74. Available from: https://linkinghub.elsevier.com/retrieve/pii/S1036731417300759

27. Li X, Fawcett T. Clinical decision making on the use of physical restraint in intensive care units. Int J Nurs Sci. 2014;1 (4):446-50. https://doi. org/10.1016/j.jijnss.2014.09.003

28. Azizpour M, Moosazadeh M, Esmaeili R. Use of physical restraints in intensive care unit: a systematic review study. Acta Med Mediterr [Internet]. 2017 [cited 2020 Sep 30];33(1):129-36. Available from: https://pdfs.semanticscholar.org/77a7/2b1aeb5ad645e5aaf0a4c7dbd0e fe3131921.pdf

29. Via-Clavero G, Claramunt-Domènech L, García-Lamigueiro A, Sánchez-Sánchez MM, Secanella-Martínez M, Aguirre-Recio E, et al. Análisis de una encuesta sobre conocimientos en contenciones mecánicas de las enfermeras de unidades de críticos. Enferm Intensiva [Internet]. 2019 [cited 2020 Sep 30];30(2):47-58. Available from: https://linkinghub.elsevier.com/retrieve/pii/S1130239918301172

30. Galazzi A, Adamini I, Consonni D, Roselli P, Rancati D, Ghilardi G, et al. Accidental removal of devices in intensive care unit: An eight-year observational study. Intensive Crit Care Nurs [Internet]. 2019 [cited 2020 Sep 30];54:34-8. Available from: https://linkinghub.elsevier.com/ retrieve/pii/S0964339719300710

31. Silva PS, Fonseca MC. Unplanned endotracheal extubations in the intensive care unit: systematic review, critical appraisal, and evidencebased recommendations. Anesth Analg. 201;114(5):1003-14. https://doi.org/10.1213/ANE.0b013e31824b0296

32. Faria H, Paiva A, Marques P. A restrição física da mobilidade: estudo sobre os aspetos ligados à sua utilização com fins terapêuticos. Rev Enferm Ref. 2012;III-Série(6):7-16. https://doi.org/10.12707/RIII1192

33. Martín Iglesias V, Pontón Soriano C, Quintián Guerra MT, Velasco Sanz TR, Merino Martínez MR, Simón García MJ, et al. Contención mecánica: su uso en cuidados intensivos. Enferm Intensiva [Internet]. 2012 [cited 2020 Sep 30];23(4):164-70. Available from: http://www.elsevier.es/ es-revista-enfermeria-intensiva-142-articulo-contencion-mecanica-su-uso-cuidados-S1130239912000727

34. Mantovani C, Nobre Migon M, Valdozende Alheira F, Marta Del-Ben C. Manejo de paciente agitado ou agressivo[Internet]. 2010 [cited 2019 Apr 30];32(Supl II):S96-S103. Available from: http://www.scielo.br/pdf/rbp/v32s2/v32s2a06.pdf

35. İsmet E, Khorshid L, Hakverdio G. The characteristics of physically restrained patients in intensive care units [Internet]. 2007 [cited 2020 Sep 30];4(2). Available from: https://www.j-humansciences.com/ojs/index.php/IJHS/article/view/190

36. Reis CCA, Sena ELS, Fernandes MH. Humanization care in intensive care units: integrative review. Rev Pesqui: Cuid Fundam. 2016;8(2):4212. https://doi.org/10.9789/2175-5361.2016.v8i2.4212-4222

37. Luiz FF, Caregnato RCA, Costa MR. Humanization in the Intensive Care: perception of family and healthcare professionals. Rev Bras Enferm. 2017;70(5):1040-7. https://doi.org/10.1590/0034-7167-2016-0281

38. Cosper P, Morelock V, Provine B. Please release me: restraint reduction initiative in a health care system. J Nurs Care Qual. 2015;30(1):16-23. https://doi.org/10.1097/NCQ.0000000000000074

39. Eskandari F, Abdullah KL, Zainal NZ, Wong LP. Use of physical restraint: Nurses' knowledge, attitude, intention and practice and influencing factors. J Clin Nurs. 2017;26(23-24):4479-88. https://doi.org/10.1111/jocn.13778 